\title{
PENGARUH PEMBERIAN EKSTRAK KUNYIT (CURCUMA LONGA) TERHADAP EKSPRESI SEL GOBLET PADA KONJUNGTIVA TIKUS (RATTUS NOVERGICUS) YANG DIINDUKSI OVALBUMIN
}

\author{
Wenna Valentine Puspitasari ${ }^{1}$, Yuliono Trika Nur Hasan ${ }^{2}$, Halida Nelasari ${ }^{3}$ \\ Fakultas Kedokteran, Universitas Muhammadiyah Malang \\ J1. BendunganSutami 188 A Malang, 65145
}

Email : valentinewenna@yahoo.co.id

\begin{abstract}
ABSTRAK
Konjungtivitis merupakan sutau peradangan konjungtiva yang ditandai dengan dilatasi pembuluh darah sehingga konjungtiva menjadi hiperemi, edema dan dapat disertai adanya discharge. Curcumin merupakan bahan aktif dari kunyit yang memiliki manfaat sebagai anti alergi. Penelitian ini bertujuan untuk mengetahui pengaruh pemberian ekstrak kunyit (Curcuma longa) terhadap ekspresi sel goblet pada konjungtiva tikus yang diinduksi ovalbumin. Penelitian ini merupakan penelitian True experimental dengan post test only group design. Sampel dibagi dalam empat kelompok perlakuan yang diberi ekstrak kunyit dengan dosis masing-masing $35 \mathrm{mg} / 200 \mathrm{grBB}, 70 \mathrm{mg} / 200 \mathrm{grBB}, 140 \mathrm{mg} / 200 \mathrm{grBB}$ secara ip pada hari ke $15 \mathrm{dan} 18 \mathrm{satu}$ jam sebelum pemberian ovalbumin serta satu kelompok kontrol positif yang hanyadiberi ovalbumin padaharike 0,7,15 dan 18 . Analisis data menggunakan Oneway Anova, bonferonni, kolerasi dan regresi. Ekstrak kunyit dapat menurunkan jumlah sel goblet secarabermakna (ANOVA $\mathrm{p}=0,000)$. Terdapathasilujiregresi linier sebesar 70,0\%. Dosis minimal yang menunjukkan efek signifikan adalah $70 \mathrm{mg} / \mathrm{kgBB}$. Ekstrak kunyit berpengaruh terhadap penurunan jumlah sel goblet pada konjungtiva tikus (Rattusnorvegicus) yang diinduksi ovalbumin
\end{abstract}

Kata kunci : Konjungtivitis Alergi, Kurkumin, Ovalbumin

\section{ABSTRACT}

Conjunctivitis is an inflammation disease in conjunctiva that marked dilatation of blood vessels become byperemia, edema and accompanied by discharge. While curcumin, active ingredients found in Turmeric has anti allergy effect.The purpose this study were to determine the influence of Turmeric extract (Curcuma longa) towards Common Rat's Ovalbumin Conjunctiva's Goblet Cell.This study were true experimental with post test only control group design. Sample were devide into 4 groups and each were given $35 \mathrm{mg} / 200 \mathrm{grBB}, 70 \mathrm{mg} /$ $200 \mathrm{grBB}, 140 \mathrm{mg} / 200 \mathrm{grBB}$ of turmeric extract via intraperitoneum on day 15 and 18 one hour before ovalbumin topical administration. While one positive control group were given ovalbumin on day 0,7,15, and 18. Analysis done using One Way Anova, bonferonni, and regression. Turmeric extract had significantly reduce the number of goblet cell ( $A N O V A p=0,000) .70,0 \%$ as linear regression test result. Minimal dose with significant effect is $70 \mathrm{mg} / 200 \mathrm{grBB}$. Turmeric extract influence the decreased numer of goblet cell on the conjunctiva of Common Rat (Rattusnorvegicus) Ovalbumin-induced Allergic Type.

Keywords : Conjunctivitis Allergy, Curcumin, Ovalbumin 


\section{PENDAHULUAN}

Kornea dan konjungtiva merupakan bagian paling superficial dari mata yang rentan terhadap berbagai macam patogen dari lingkungan. Salah satu penyakit yang sering mengenai mata adalah konjungtivitis. Konjungtivitis merupakan suatu peradangan konjungtiva yang ditandai dengan dilat asi pembuluh darah sehingga konjungtiva menjadi hiperemi, edema dan dapat disertai adanya discharge.(Azari AA, \& Barney NP, 2013)

Menurut Ramadhanisa A (2014), insidensi konjungtivitis di Indonesia saat ini menduduki tempat kedua $(9,7 \%)$ dari 10 penyakit mata utama. Konjungtivitis alergi pada umumnya bersifat self limited tetapi dalam perkembangannya bisa mengakibatkan kehilangan penglihatan secara perma nen atau kerusakan struktural dari konjungtiva seperti pada atopic keratokonjungtivitis (American Academy of Ophthalmology, 2013). Penggunaan obat antibiotik dan kortikosteroid sebagai terapi penyakit mata makin luas yang dalam jangka panjang dapat menyeb abkan katarak subskapsular dan dapat meningkatkan tekanan intraocular. ${ }^{(6)}$.Hazarika AK, 2015 Oleh sebab itu diperlukan pengobatan lain yang mempunyai efek terapi maksimal namun minimal toksisitas dan efek sampingnya salah satunya adalah kurkumin.(Singletary K, 2010)

Kurkumin merupakan bahan aktif dari kunyit yang dapat menghambat sejumlah mediator inflamasi yaitu leukotrien. Menurut penelitian Dartt DA (2011) menunjukkan bahwa reaksi inflamasi menstimulasi sekresisel goblet melalui leukotrien yang diproduksi oleh asam arakidonat.(Dartt, et al, 2011). Sementara kandungan anti inflamasi kunyit dapat menghambat asam arakidonat melalui down regulation pada jalur cyclooxygenase dan lypoxygenase. Dengan demikian kurkumin dapat menurunkan ekspresi sel goblet.(Jurenka JS, 2009)

\section{METODE}

\author{
Desain Penelitian \\ Desain penelitian ini merupa kan Truec \\ Experimental dengan post test only group design. Penelitian \\ dilakukan di Laboratorium Biomedik dan \\ Farmakologi Fakultas Kedokteran Universitas \\ Muhammadiyah Malang selama 1 bulan.
}

Penginduksian Tikus

Hewan coba dibagi menjadi 4 kelompok yaitu, kelompok $\mathrm{K}(+)$ dan 3 kelompok perlakuan (P1, P2, dan P3). Keempat kelompok tersebut diberi ovalbumin+ALUM secara ip (intraperitoneal) pada hari ke 0 dan hari ke 7 , selanjutnya diberikan Ovalbumin secara topikal pada sakkus konjungtiva pada hari ke 15 dan hari ke 18.

\section{Pembuatan dan Pemberian Ekstrak Kunyit}

Timbang serbuk rimpang kunyit sebanyak 100gr, masukkan serbuk yang telah ditimbang ke dalam toples, diratakan dan sambil ditambahkan pelarut etanol $96 \%$ sampai bahan terendam, total yang ditambahkan sebanyak $1 \mathrm{~L}$. Tutup toples dengan rapat selama 72 jam dam dishaker di atas shaker digital $50 \mathrm{rpm}$, kemudian saring ekstrak cair dengan penyaring kain dan tampung ekstrak dalam erlenmeyer. Hasil ekstrak cair diuapkan dengan menggunakan rotary evaporator selama 1 jam. Ekstrak cair yang dihasilkan kemudian dievaporasi / diuapkan kembali diatas water bath selama 2 jam. Didapatkan ekstrak kunyit cair sebanyak 8 gram.

Ekstrak yang sudah dibuat diberikan pada ketiga kelompok perlakuan dengan dosis masingmasing yaitu $35 \mathrm{mg} / 200 \mathrm{gBB}, 70 \mathrm{mg} / 200 \mathrm{gBB}$, dan $140 \mathrm{mg} / 200 \mathrm{gBB}$ yang diberikan secara ip (intraperitoneal) pada hari ke 15 dan hari ke 18 yang diberikan 1 jam sebelum pemberian ovalbumin secara topikal.

\section{Evaluasi Sel Goblet}

Jaringan konjungtiva tikus diambil pada hari ke 18, sebelumnya tikus dianestesi terlebih dahulu dengan kloroform lalu dilanjutkan dengan penghitungan ekspresi sel goblet pada konjungtiva dan dilanjutkan dengan analisis data. 


\section{HASIL DAN PEMBAHASAN}

Hasil penghitungan jumlah sel goblet pada konjungtiva tikus ditunjukkan hasil pada tabel dibawah ini :
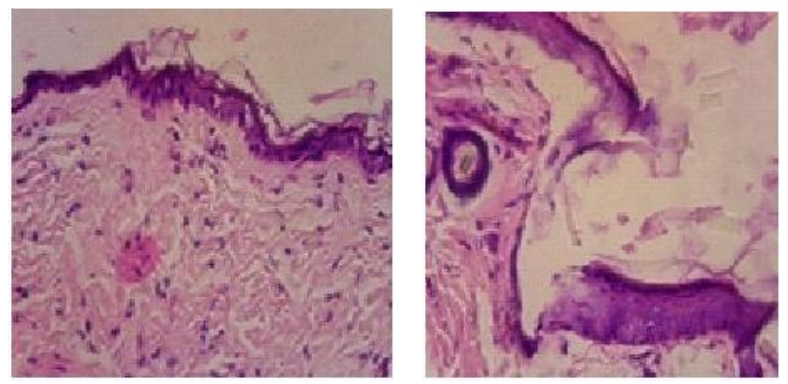

\begin{tabular}{|l|c|c|c|c|c|c|c|c|}
\hline \multirow{2}{*}{ Kelompok } & \multicolumn{7}{|c|}{ JumlahSel Mast } & \multirow{2}{*}{ Rata-rata } \\
\cline { 2 - 9 } & $\mathbf{1}$ & $\mathbf{2}$ & $\mathbf{3}$ & $\mathbf{4}$ & $\mathbf{5}$ & $\mathbf{6}$ & $\mathbf{7}$ & \\
\hline K Positif & 25 & 22 & 24 & 23 & 24 & 27 & 23 & 24 \\
\hline $\begin{array}{l}\text { P1 } \\
(35 \mathrm{mg} / 200 \mathrm{gBB})\end{array}$ & 25 & 23 & 22 & 24 & 22 & 21 & 22 & 22,7 \\
\hline $\begin{array}{l}\text { P2 } \\
(70 \mathrm{mg} / 200 \mathrm{gBB})\end{array}$ & 20 & 20 & 21 & 19 & 20 & 21 & 20 & 20,1 \\
\hline $\begin{array}{l}\text { P3 } \\
(140 \mathrm{mg} / 200 \mathrm{gBB})\end{array}$ & 18 & 15 & 13 & 14 & 17 & 16 & 13 & 15,1 \\
\hline
\end{tabular}
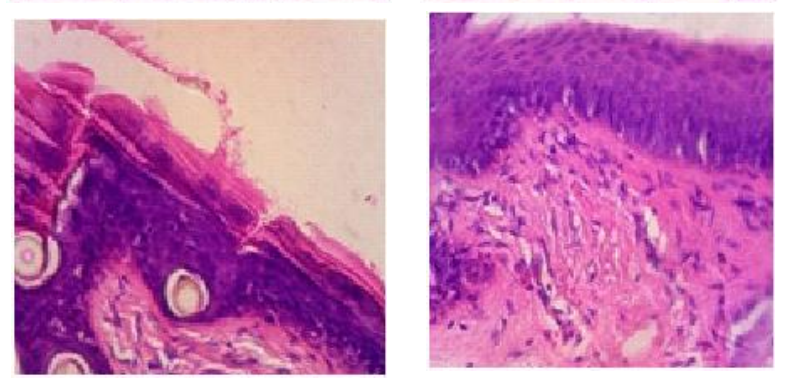

Gambar 1.Perbedaan Jumlah Ekspresi Sel Goblet Tikus (Pengecatan HE dengan Pembesaran 400x) pada konjungtiva tikus pada berbagai kelompok. Pada kelompok perlakuan III, yaitu kelompok yang diberikan ekstrak kunyit sebesar $140 \mathrm{mg} / 200$ grBB (Gambar D) paling sedikit dibandingkan dengan kontrol positif yang hanya diberikan ova dan alum (Gambar A), kelompok perlakuan I, yaitu kelompok yang diberikan ekstrak kunyit sebesar $35 \mathrm{mg} / 200$ grBB (Gambar B), kelompok perlakuan II yaitu kelompok yang diberikan ekstrak sebesar $70 \mathrm{mg} / 200 \mathrm{grBB}$ (Gambar C)

Data-data yang diperolah dilakukan uji normalitas (Saphiro-Wilk) dan didapatkan nilai 0,345, selanjutnya dilakukan uji homogenitas (Levene) dan didapatkan nilai 0,354 . Dari uji normalitas dan homogenitas didapatkan nilai yang signifikan karena nilai $\mathrm{p}>0,05$ sehingga dapat dilanjutkan dengan
Analisis One Way Anova. Dari uji One Way Anova didapatkan nilai 0,000 artinya terdapat perbedaan jumlah sel goblet antar kelompok.Uji Post Hoc Bonferroni dilakukan untuk mengetahui perbandingan jumlah sel goblet antara setiap kelompok perlakuan, dengan hasil sebagai berikut :

\begin{tabular}{|c|c|c|c|}
\hline \multicolumn{2}{|c|}{$\begin{array}{c}\text { Perbandingan antar } \\
\text { Kelompok }\end{array}$} & Signifikansi & Kesimpulan \\
\hline \multirow{3}{*}{$\mathrm{K}+$} & P1 & 1.000 & Tidak Berbeda signifikan \\
\hline & P2 & 0.031 & Berbeda signifikan \\
\hline & P3 & 0.000 & Berbeda signifikan \\
\hline \multirow{2}{*}{ P1 } & P2 & 0.111 & Tidak Berbeda signifikan \\
\hline & P3 & 0.000 & Berbeda signifikan \\
\hline P2 & P3 & 0.014 & Berbeda signifikan \\
\hline
\end{tabular}


Tabel 2. Uji Post Hoc Bonferroni

Hasil Uji Post Hoc didapatkan adanya perbedaan jumlah ekspresi sel goblet antara kelompok kontrol positif dengan kelompok perlakuan yang ditambahkan dengan ekstrak kunyit. Hal ini dikarenakan OVA yang merupakan protein alergenik jika diberikan secara inhalasi, oral, maupun intraperitoneal terbukti dapat menyebabkan terjadinya respon imun IgE spesifik, Th2, produksi sitokin dan infiltrasi eosinofil ke dalam konjungtiva. Hal ini terjadi karena OVA akan memicu APC yang akan didegradasi menjadi peptida-peptida dan selanjutnya akan dipresentasikan pada sel Th2. Teraktivasinya Th2 akanmenginduksiproduksi mediator inflamasiseperti histamine, leukotrien, dansitokin (Subijanto AA \& Diding HP, 2008)

Berdasarkan table analisis uji Post Hoc diatas dapat menjelaskan bahwa terdapat perbedaan penurunan jumlah ekspresi sel goblet yang bermakna antara setiap kelompok perlakuan kecuali kontrol (+) dengan P1, dan P1 dengan P2. Tidak didapatkan perbedaan yang signifikan antara kelompok kontrol (+) dengan kelompok perlakuan 1 dikarenakan dosis pemberian ekstrak kunyit b elum mencapai rentang efek terapi. Hal ini juga sesuai dengan penelitian yang dilakukan oleh Ram et al (2003) yang menunjukkan bahwa marmot yang diinduksi OVA kemudian diberikan ekstrak kunyit sebesar $200 \mathrm{mg}$ (setara dengan 45,6 mg/200grBB tikus) signifikan dalam menghambat re aksi hipersensitifitas pada alergi respiratori yang ditunjukkan dengan penurunan jumlah Ig Edaneosinofil.(Ram A, Das $M$, Ghosh B, 2003) Sementara pada pe rlakuan dosis kurkumin masih dibawah 45,6 mg. Hal inijuga dipengaruhi karena cara penginduksiannya melalui intraperitoneal. Meskipun intraperitoneal merupakan rute pemberian secara parenteral, tetapi sifat farmakokinetiknya menyerupai de ngan pemberian secara peroral. Oleh sebab itu zat intra peritoneal akan mengalami metabolism hepatic sebelum mencapai sirkulasi sistemik. Sehingga dosis yang diperlukan juga harus lebih banyak.

Pada kelompok perlakuan 2 dan 3 didapatkan perbedaan yang signifikan artinya dosis terse but sudah memberikan efek penurunan terhadap ekspresi sel goblet secara bermakna. Hal ini terjadi karena kurkumin yang terkandung dalam kunyit mampu menghambat COX-2 melalui inaktivasi NF-kB. NF-kB merupakan faktor transkripsieukariotik yang terlibat dalam regulasi peradangan, proliferasisel, transformasi dan tumorigenesis. Penekanan pada NF-kB akan menurunkan produksi COX-2 dan melalui down regulation ini asam arakidonat akan turut terhambat. (Jurenka JS, 2009) Menurut penelitian Darrt (2011) menunjukkan bahwa CysLT menstimulasi sekresisel goblet melalui LTD4 yang diproduksi oleh asam arakidonat.(Dartt, et al, 2011)

Berdasarkan ketiga dosis ekstrak kunyit diatas, pemberian ekstrak mempengaruhi pengaruh yang berbeda terhadap jumlah ekspresi sel goblet. Semakin tinggi dosis ekstrak kunyit yang diberikan maka jumlah sel goblet akan semakin rendah. Perbandingan tersebut disimpulkan bahwa dosis ke 3 mampu menurunkan ekspresi sel goblet lebih besar dari 2 dosis lainnya karena kelompok perlakuan 3 diinduksi ekstrak kunyit paling besar. Hal ini terjadi karena kurkumin yang terkandung dalam kunyit menghambat reaksi anafilaktik sistemik in vitro dan anti dinitrophenylimmunoglobulin $E$ (Anti DNP IgE). Jika reaksi ini dihambat maka mediatormediator farmakologis aktif, salah satunya adalah leukotrien sebagai stimulus sekresisel goblet juga turut terhambat. (Baratawidjaja KG \& Rengganis I, 2013). Dari uji regresi linier didapatkan nilai Adjusted $R$ square sebesar $70 \%$ sebanyak $30 \%$ lainnya merupakan zat-zat atau faktor lain yang tidak diteliti namun juga dapat berpengaruh terhadap penurunan jumlah sel goblet, yaitu faktor endogen dan eksogen. Faktor endogen antara lain berupa adanya leukosit dan turunannyadansellainnya yang mempunyai peranan dalam pertahanan seluler dan humoral terhadap benda-benda asing serta kelibatan TNFá. ${ }^{(5)}$ Effendi Z, 2003 Selain itu menurut Serhan CN (2008) leukosit bersamaan dengan lipoksin dan mediator kimia endogen yang disebut dengan resolvin dan proteksin men gendalikan respon inflamasi lokal pada berbagai tingkatan untuk merangsang perbaikan jaringan.(Serban CN, 2008) Sementara faktor eksogen berupa (1) Faktor lingkungan berupa kelembapan dan paparan cahaya selama masa perlakuan yang akan meningkatkan respon stress. (2) Faktorgenetik. (3) Faktor dari kandungan ekstrak kunyit. Secara keseluruhan dari hasil penelitian ini didapatkan bahwa pemberian ovalbumin selama 18 hari dapat menyebabkan reaksi alergi yang bermakna pada konjungtiva tikus dan dengan pemberian ekstrak kunyit (Curcuma 
longa) dapat menurunkan jumlah sel goblet tikus yang diinduksialergen (OVA).

\section{KESIMPULAN}

Berdasarkan hasil penelitian dapat disimpulkan bahwa :

1. Ada pengaruh pemberian ekstrak kunyit (Curcuma longa) terhadap ekspresi sel goblet pada konjungtiva tikus (Rattus novergicus) yang diinduksi OVA

2. Ada perbedaan penurunan jumlah ekspresi sel goblet pada masing-masing kelompok perlakuan. kelompok P1 (3,46\%), P2 (17,87\%), P3 (37,7\%).

3. Dosis minimum yang dapat memberikan efek penurunan terhadap jumlah ekspresi sel goblet pada penelitian ini adalah pada perlakuan dosis $2(70 \mathrm{mg} / 200 \mathrm{grBB})$.

\section{DAFTAR PUSTAKA}

American Academy of Ophthalmology, 2013, Conjunctivitis, Preffered Practice Pattern, pp.148.

Azari AA, \& Barney NP, (2013), Conjunctivitis: A Systematic Review of Diagnosis and Treatment. JAMA Clinical Review \& Education, 310 (16), pp. 1721 - 1729.Borges AS, 2013, Anatomy of Ciliary Body, Ciliary Processes, Anterior Chamber Angle and Collector Vessels, INTECH, pp. 1-13.

Baratawidjaja KG \& Rengganis I, 2013, Imunologi Dasar, $10^{\text {th }}$ edn, Fakultas Kedokteran Universitas Indonesia, Jakarta, pp.375-378.

Dartt, et al, 2011 DA, Hodges RR, Li Dayu, et al, 2011, Conjunctival Goblet Cell Secretion Stimulated by Leukotrienes is Reduced by Resolvins D1 and E1 to Promote Resolution of Inflammation, The Journal of Immunology, 186, pp. 44554466.

Effendi Z, 2003, PerananLenkositSebagai Anti InflamasiAlergikdalamTubuh, Digitized by USU Digital Library, 1, pp.1-8.

Hazarika AK, 2015, Benefits and Risk of Topical Corticosteroid in The Management of Ocular Inflammation, Sikkim Manipal University Medical Journal, 2(2), pp. 295-305.

Jurenka JS, 2009, Anti-inflammatory Properties of Curcumin, a Major Constituent of Curcuma longa
: A Review of Preclinical and Clinical Research, Alternative Medicine Review, 14, pp. 141153.

Ram A, Das M, Ghosh B, 2003, Curcumin Attenuates Allergen-Induced Airway Hyperresponsiveness in Sensitized Guinea Pigs, Biol Pharm Bull. 26, pp.1021-1024.

Ramadhanisa A, 2014, Conjunctivitis Bacterial Treatment in Kota Karang, Medula Unila, 3, pp. 1-7.

Serhan CN, Chiang N, Dyke TEV, 2008, Resolving Inflammation: Dual Anti-Inflammatory and Proresolution Lipid Mediator, Nature Review Immunology, 8, pp. 349-361.

Singletary K, 2010, Turmeric an Overview of Potential Health Benefits, Nutrition Today, 45, pp. 216225.

Subijanto AA \& Diding HP, 2008, Pengarub Minyak Biji Jintan Hitam (Nogella sativa L.) 